CDD - 869.4B

\title{
O BRUXO DO COSME VELHO DECRETOU A MORTE DO DIABO
}

\section{Salma Ferraz ${ }^{*}$}

Resumo: No presente artigo pretende-se pontuar alguns aspectos da trajetória de Lúcifer na Bíblia, na Teologia, na crítica e nos contos Adão e Eva, A Igreja do Diabo e O Anjo Rafael, de Machado de Assis. Palavras-chave: Teologia. Literatura. Diabo. Machado de Assis. Adão e Eva. A Igreja do Diabo. O Anjo Rafael.

Abstract: This article seeks to investigate some aspects of the trajectory of Lucifer in the Bible, in Theology, in literary criticism, and in the short stories Adão e Eva, A Igreja do Diabo and O Anjo Rafael, by Machado de Assis.

Keywords: Theology. Literature. Devil. Machado de Assis. Adão e Eva. A Igreja do Diabo. O Anjo Rafael.

Chamo-me Lúcifer, aquele que traz a luz. Assim cantavam os anjos menores, até que lhes foi proibido este canto. Desde então, meu apelido corrói os tempos anunciando aquele que arma ciladas. Bazófia: o homem dispensa Satanás e sabe perder-se por si mesmo. (SANTOS, 1996, p.121).

Se a glória de Deus é encobrir, como relata Provérbios 25: 2, parece que a glória dos escritores é investigar: creio, logo duvido; não creio, logo questiono. Entre as maiores perguntas do Ocidente estão estas: Deus existe? Quem criou Deus? Entre tantos estudiosos desse assunto citamos três, com suas obras mais recentes: Deus, uma Biografia, de Jack Miles; Deus, um Delírio, de Richard Dawkins; e Tratado de Ateologia, de Michel Onfray. No entanto, por que não colocar a questão da existência divina a partir de um olhar antiteticamente teológico? O Diabo existe? Você acredita no Diabo?

\footnotetext{
* Professora de Língua e Literatura Vernáculas da Universidade Federal de Santa Catarina; Doutora em Literatura Portuguesa pela Universidade Estadual de São Paulo (UNESP), dirige o grupo de pesquisa denominado Teopoética - Os Estudos Comparados entre Teologia e Literatura. Suas últimas publicações intitulam-se As Faces de Deus na obra de um Ateu - José Saramago (publicada pela Editora da FURB \& Editora da UFJJ em 2003) e No princípio era Deus e ele se fez poesia (EDUFAC, 2008).

Uniletras, Ponta Grossa, v. 30, n. 1, p. 175-198, jan./jun. 2008 Disponível em <http://www.uepg.br/uniletras>
} 
Não são poucas as obras dedicadas a Lúcifer ou Satanás, mais comumente conhecido por Diabo, além de centenas de apodos nada elogiosos. Não nos compete, em tão pouco espaço, a ontológica tarefa de debater o problema da existência ou não do Diabo; isso pertence aos demonólogos. Uma vez constatada a inquestionável presença do Diabo na teologia cristã e na literatura ocidental, pontuaremos alguns aspectos das possíveis biografias do Diabo na Bíblia e na Literatura, para embasar nossas reflexões sobre o Diabo em Machado de Assis. Neste artigo, nos interessam cinco momentos específicos: $\mathrm{O}$ Diabo na Bíblia, o Diabo e os Teólogos, o Diabo e os Teóricos, O Diabo e a Literatura Ocidental, e o Diabo em Machado de Assis.

Sobre Deus, o pensador alemão Leibniz já escreveu sua Teocidéia : mas, afinal, quem escreveu a odisséia de Lúcifer? Ninguém quer defender o chamado Anjo Caído? Algumas vozes luciferinas do terceiro milênio já são ouvidas, das quais citamos três (outras estão listadas na bibliografia final): $A$ Biografia do Diabo, de Alberto Cousté; História Geral do Diabo, de Gerard Messadié; e Uma História do Diabo, de Robert Muchembled. Parece-nos, com essa abertura ao questionamento sobre a existência de Lúcifer, que é a hora e a vez do tinhoso, aquele cujo nome as pessoas preferem não pronunciar.

\section{O Diabo na Bíblia}

Se observarmos com cautela o Antigo Testamento, constataremos que não existe menção ao Diabo. O Diabo nasceu, fecundou e procriou junto com o cristianismo. No Antigo Testamento temos o episódio da tentação e da serpente que provocou a queda de Adão e Eva ${ }^{2}$, relatado em Gênesis 3; depois, o ritual envolvendo o dia da expiação e o bode expiatório em Levítico 16; e, mais à frente, o surpreendente Livro de Jó, no qual aparece pela primeira vez Satanás. Com relação ao episódio da serpente, provavelmente foi escrito por influência de mitologias ou lendas de outras culturas no Oriente Médio com as quais os judeus tiveram contato, já que a serpente, nessas culturas, era

\footnotetext{
${ }^{1}$ A Teodicéia é um campo da Teologia natural que defende a onipotência, a onisciência, a justiça e a bondade de Deus. É contra a idéia de que a presença do mal e do sofrimento no mundo reduze ou minimiza os atributos divinos. Essa expressão foi criada por Leibniz, em sua obra Teodicéia, publicada em 1710. Nesse ensaio o filósofo debatia a bondade de Deus, tentava um tratado racional sobre Deus, sobre a liberdade do homem e a origem do mal. Perante o problema do mal, o filósofo assumiu uma posição otimista, concluindo que o mundo criado por Deus ainda é o melhor dos mundos possíveis.

${ }^{2}$ Gênesis 6 traz outra versão da queda: a união antinatural de seres celestiais com as filhas dos homens, o que resulta na criação de uma raça de gigantes. 
símbolo de sabedoria, astúcia e poderes maléficos, e foi por isso tardiamente associado ao Diabo.

A simbologia do bode expiatório é riquíssima e um tanto controvertida. Teses e mais teses já foram escritas. Umas indicam o bode expiatório como sendo Jesus, porque ele carrega as culpas e é morto no deserto; outros defendem que o bode expiatório é o Diabo, já que ele é o responsável pela culpa dos humanos, pois fez os primeiros pais pecarem, o primeiro Adão falhar. $\mathrm{O}$ importante é frisar que, com o tempo, o bode passou a ser também associado somente ao Diabo.

Na seqüência, um dos livros mais sensivelmente filosóficos de todo o Antigo Testamento é o Livro de Jó, o big brother celestial. Deus provoca Satanás - que nesse livro é identificado como "um dos filhos de Deus” que freqüentava o céu com muita intimidade e liberdade - para uma disputa, onde os dois observariam tudo do camarote. Jung, em Resposta a Jó, afirma que Satanás talvez seja um dos olhos de Deus que perambula sem rumo certo pela terra. (JUNG, 2001, p. 16). Jó vai duas vezes para o paredão, sem clemência alguma. Na primeira vez, Deus permite que Satanás tire tudo o que ele tem fazendas, filhos, servos, bens - e mesmo assim Jó vence. Não satisfeito, Deus pela segunda vez o envia para a beira do abismo e permite que Satanás toque em sua carne, mas Jó não renega a Deus e triunfa novamente. A alma de Jó é oferecida numa bandeja para Satanás, pois há um pacto entre Deus e Satanás. E não seria exagero dizer que, muito antes de Marlowe, Shakespeare, Goethe, Tomás Mann, Paul Valéry, Guimarães Rosa, o mito de Fausto nasceu aqui, com uma diferença: Jó não sabia de pacto algum.

Dezenas de livros e teses já foram escritos sobre Jó e a partir deles nos permitimos fazer algumas considerações. ${ }^{4}$ O Livro de Jó consiste em uma teologia do sofrimento, pois nele, pela primeira vez, o caráter e a justiça de Deus são questionados por um pobre mortal que sofre muito além de suas forças. Em verdade o confronto não se dá entre Satanás e Jó, mas sim entre Deus e Jó, uma vez que Satanás é apenas um instrumento para realizar a vontade de Deus. Aqui se acentua o caráter destrutivo de Javé. Jó questiona a justiça

\footnotetext{
${ }^{3}$ Em Números 21-8, o símbolo da serpente é positivo. O Senhor, enraivecido contra o seu povo, manda um ataque de serpentes abrasadoras. Moisés intercede pelo povo e Deus manda-o fazer uma serpente de bronze e colocá-la sobre uma haste. Quem era mordido pela serpente abrasadora olhava para a serpente de bronze e se curava.

${ }^{4}$ Sobre esse assunto, pode-se consultar os livros Resposta a Jó, de C. G. Jung, e Jó - a força do escravo, de Antonio Negri, e também o capítulo Confronto, do livro Deus, uma biografia, de Jack Miles.
} 
divina e Deus não responde ao que ele pergunta, considera isso uma ousadia, sente-se embaraçado e o esmaga, mostrando não sua justiça, mas seu poder, com discurso arrasador.

Se Deus era onisciente, por que provocou Satanás? Afinal, nem ele pode ser tentado além do que pode resistir... $\mathrm{O}$ autor desse livro [...] imagina Jó sofrendo em um mundo governado por um deus que faz apostas com o demônio, manipulado e controlado por um demônio. (MILES, 1997, p. 347). Retomamos nossa idéia, anteriormente já exposta: essa aposta funda o pacto e o mito de Fausto, enfim, revela-nos um mundo regido por dois demônios orgulhosos e, a partir daí, o caráter demoníaco do Senhor Deus. O imenso discurso de Deus de nada serve. O silêncio de Jó é o silêncio dos vencedores, e o silêncio de Deus é o silêncio dos perdedores. A partir de então Deus não fala mais no restante do Antigo Testamento.

Explicitamos aqui toda essa rápida exegese para ilustrar que, no Antigo Testamento, não existe a figura do Diabo. Tanto o bem quanto o mal procedem de Deus. Citamos alguns exemplos: a destruição de Sodoma e Gomorra, a Torre de Babel, as dez pragas do Egito. Corrobora nosso pensamento Messadié que, em sua História geral do Diabo, afirma:

Deus é assim, no Antigo Testamento, simultaneamente o Bem e o Mal. O Diabo não é senão o seu servidor e nunca se encontra o conflito que colora tão fortemente o Novo Testamento, onde o Diabo aparece sempre como o inimigo de Deus e o Príncipe deste mundo, em oposição ao Rei dos céus [...] a teologia do Antigo Testamento não concebe senão um pólo único no universo, e o Diabo nunca tem aí senão um papel conforme à vontade do Criador. Satanás é o Mal? Não, ele é o sofrimento pretendido pela vontade de Deus. (MESSADIÉ, 2001, p.303, negrito nosso).

O Novo Testamento já inicia com o episódio envolvendo o Diabo: a famosa tentação de Jesus, relatada em Mateus IV. Ele é descrito como o tentador, mas Jesus não se assusta com sua presença, parece que são conhecidos de longa data. Se pensarmos na inteligência de Lúcifer e sua magnífica revolta, que levou consigo a terça parte dos anjos, as perguntas do Diabo são simplesmente ridículas. Como todos sabem, Jesus resiste à tentação. Em todo o Novo Testamento são muitos os casos de possessão demoníaca, como, por exemplo, o endemoninhado de Gadara. Jesus curou diversos endemoninhados, e a palavra demônio passou a ser associada ao Diabo. 
Aqui temos um problema com a etimologia da palavra. No Velho Testamento, Satan é uma palavra em hebraico que significa adversário. Em Jó, Satanás é um Membro do Conselho de Deus. Até aqui, Satan não é o Diabo, só se tornará o Diabo pelos comentaristas cristãos. O problema ocorre quando o Diabo passa a ser designado pela palavra dáimon ou demônio. Luther Link esclarece que um dáimon era um espírito mediador entre deuses e homens. (LINK, 1998, p. 25).

Esse dáimon poderia ser um espírito bom ou perverso, porém na tradução do Novo Testamento para o grego a palavra dáimon manteve somente a acepção de espírito do Mal. Aqui está, portanto, a origem do termo endemoninhado: aquele que estava possuído pelo Diabo. Na realidade, Quevedo, em sua obra Antes que os Demônios voltem, esclarece que todos os casos de possessão demoníaca do Novo Testamento referiam-se a pessoas com sérios distúrbios psíquicos. O Novo Testamento se desenrola e o Diabo progride junto com ele. O evangelista Lucas informa que Satanás entrou em Judas e por isso Judas traiu Jesus. Deduzimos, então, que Judas era inocente. O próprio Jesus foi acusado pelos fariseus de estar endemoninhado, já que, segundo eles, expulsava demônios pelo poder de Belzebu. Lucas faz com que os demônios sejam os primeiros a reconhecerem a divindade de Jesus, ao afirmarem: Ah! Que temos nós contigo, Jesus Nazareno? Bem sei que és o santo de Deus!

O evangelista João aponta o Diabo como sendo homicida desde o princípio do mundo, pai da mentira e príncipe do mundo. Na seqüência o apóstolo Paulo, em todas as suas cartas, amedronta os cristãos de sua época fomentando a existência do Diabo. É São Pedro quem afirma em seu evangelho: Sede sóbrios e vigilantes. O diabo, vosso adversário, anda de derredor, como o leão que ruge procurando alguém para devorar; resisti-lhe firmes na fé. (PEDRO 5:8)

É no Apocalipse, entretanto, escrito em torno do ano 100 d.C, que finalmente é estabelecida a conexão entre a revolta de Lúcifer, a queda dele e da terça parte dos anjos, a queda de Adão e Eva e o episódio da serpente no paraíso, a tentação de Jesus e o grande Armagedon - a batalha final do bem contra o mal:

Houve peleja no céu. Miguel e os seus anjos pelejaram contra o dragão. Também pelejaram o dragão e seus anjos; todavia, não prevaleceram;

${ }^{5}$ Lucas 4.34. 
nem mais se achou no céu o lugar deles. E foi expulso o grande dragão, a antiga serpente, que se chama Diabo e Satanás, o sedutor de todo o mundo, sim, foi atirado para a terra, e com ele, os seus anjos. (APOCALIPSE 12, 7-9, negrito nosso)

Robert Muchembled, em seu livro Uma história do Diabo, resume as conexões da trajetória de Lúcifer/Serpente/Satanás/Diabo:

Precisaram, assim, casar a história da serpente com a do rebelde, do tirano, do tentador, do sedutor concupiscente e do dragão todo-poderoso. Um autor declarou recentemente que a vitória do cristianismo neste domínio consistiu em tomar emprestado um dos mais importantes modelos narrativos do Oriente Próximo: o mito cósmico do combate primordial entre os deuses, que tem na condição humana seu desafio fundamental. Esta versão pode, segundo ele, ser assim resumida: um diabo rebelde ao poder de Jeová faz da terra uma extensão de seu império para nela reinar pelo poder do pecado e da morte. "Deus deste mundo”, como o denomina São Paulo, ele é combatido pelo filho do Criador, o Cristo, por ocasião do mais misterioso episódio da historia cristã, a Crucificação, que combina uma derrota e uma vitória simultâneas. A função de Cristo no decurso dessa luta, que só terminará no fim dos tempos, é ser o libertador potencial da humanidade, em confronto com Satã, seu adversário por excelência. (MUCHEMBLED, 2001, p. 19).

Do Diabo bíblico passemos para o Diabo dos teólogos, afinal a teologia se ocupa dele quase tanto quanto Deus, uma vez que a criatura se tornou tão famosa quanto seu criador.

\section{O Diabo e os Teólogos}

Na Teologia muitas foram as obras e muitos foram os concílios que trataram da trajetória e da existência de Lúcifer, e seria uma tarefa hercúlea relacioná-los. Por outro lado, registramos algumas referências: Peter Kreeft, jesuíta americano, afirma que a existência do Diabo é um dogma de fé e cita como fonte o $4^{\circ}$ Concílio de Latrão, de 1215 . Essa mesma idéia estaria no Catecismo. Segundo a interpretação de Kreeft sobre o Concílio de Latrão, Satanás e os outros demônios são por natureza espíritos criados por Deus e, portanto, originalmente bons, mas caíram no pecado no exercício de sua vontade livre. A existência de Deus e a existência de Satanás são dogmas do Cristianismo, e negar a existência tanto de um como de outro é considerado heresia. 
A Igreja Católica, a Bíblia e os dogmas confirmam a existência de Lúcifer. Nenhum Papa, nenhum Concílio jamais pôs em dúvida essa existência. O exegeta jesuíta J. M. Martins Terra, em sua obra Existe o Diabo? Respondem os Teólogos, esclarece que:

Não há dúvida alguma que Paulo VI espelha fielmente o Magistério ordinário, bi-milenário da Igreja, quando pronuncia estas palavras. A existência do Diabo nunca foi negada por nenhum Papa, nenhum Concílio, nem nunca foi posta em dúvida por nenhum heresiarca. Sem dúvida alguma é uma verdade de Fide Divina et Catholica pelo Magistério Ordinário da Igreja. Logo é um dogma de fé. (TERRA, 1975, p. 277- 278, negrito nosso).

Ou seja, crer no Diabo é um dogma de Fé e o Sínodo I de Braga, sob o comando do Papa João III, afirma que, se alguém pensar de forma diferente, pode ser considerado anátema. ${ }^{6}$ O próprio Concílio Vaticano II menciona a existência do demônio, porém após esse Concílio surgiram algumas heresias sobre esse tema e houve certa apostasia de uma parte do clero. Ocorreu o que se denominou de exegese moderna. A partir de então surgem, nas últimas décadas, as idéias do protestante R. Bultmann, teórico da chamada "desmitização", que consiste na negação de todos os milagres, de todo o sobrenatural dos Evangelhos. Isso é levado às últimas conseqüências por alguns de seus discípulos, que passaram a adotar o nome significativo de "teologia da morte de Deus”. Quanto a isso, Martins Terra esclarece que:

Os discípulos de Bultmann, sobretudo os teólogos da "Teologia da morte de Deus" foram menos hipócritas, mais coerentes e puseram a nu toda a verdade. [Para eles] Não foram somente os anjos e demônios que morreram, mas sim o próprio Deus. De fato toda essa literatura que versa sobre a impossibilidade de anjos e demônios é bastante ambígua. Basta, porém, trocar a palavra anjo e demônio pela palavra Deus e ela perderá toda a sua equivocidade, mostrando toda a sua significação e adquirindo uma densidade profundamente filosófica. (TERRA, 1975, p. 196, negrito nosso).

Essa chamada heresia se infiltrou sorrateiramente no clero católico. A dúvida da existência ou não de anjos e demônios, bem como a dúvida sobre a existência de Deus, chegaram à alma da Teologia Católica por meio da exegese

\footnotetext{
${ }^{6}$ Em 2007 o Papa Bento XVI, em um sermão em Roma, reiterou a existência do Inferno, não como imagem literária, mas realmente como um lugar em que as pessoas queimam pela eternidade. 
moderna. Observemos que a Teologia da morte de Deus implica também a Teologia da morte do Diabo. Outros teólogos vão em direção oposta, não negam a existência de Deus ou a existência do Diabo, nem a morte de um ou outro; declaram que ambos pertencem à esfera do sagrado e que o ponto de vista do observador é que vai qualificar a natureza do sagrado - se positivo ou negativo, divino ou demoníaco. Deus e o Diabo aparecem então como construções mentais, símbolos explicativos para o mesmo e único Sagrado Incondicional ou o Deus-acima-de-Deus do qual Tillich fala em A coragem de Ser.

A primeira menção do demônico em Tillich ocorre num artigo de 1923 sobre o Socialismo Religioso, chamado Grundlinien des religiösen Sozialism. No entanto, a articulação do conceito começa a firmar-se realmente em sua obra Filosofia da Religião, de 1925. Nessa obra, o demônico aparece em contraposição ao divino e ambos estão inseridos na esfera do Sagrado. Para Tillich, $o$ demônico é o Sagrado precedido por um sinal 'menos': o antidivino sagrado (1969, p. 74, negrito nosso), o sagrado negativo, destrutivo. Entretanto ainda é sagrado, uma vez que provém do mesmo abismo de onde flui a graça.

A despeito das posteriores revisões que Tillich fez do conceito de demônico, continuam a persistir elementos da mística de Böehme ${ }^{7}$ - o demônico participa do próprio Abismo incondicional; da ontologia de Schelling ${ }^{8}$ - as

\footnotetext{
7 Jakob Böhme (1575-1624), filósofo e místico alemão, foi educado dentro do luteranismo e foi acusado de heresia pelo teor polêmico de suas obras. Após diversas visões e experiências místicas, publicou seus livros: Aurora (Die Morgenroete im Aufgang, 1610), Christosophia (der Weg zu Christo, 1623), (De Signatura Rerum e Misterium Magnum 1618-1624). Seus discípulos se espalharam por toda a Europa e ficaram conhecidos como os boehmistas. Seus estudos centravam-se na natureza do pecado, do bem e do mal. Cria que Deus restauraria o mundo ao estado primitivo da graça. Atualmente suas obras são estudadas e admiradas por diversas comunidades de espiritualistas, místicos, martinistas, teosofistas e filósofos em todo o mundo.

${ }^{8}$ Friedrich Wilhelm Joseph Schelling, (Wurttemberg, 27/01/ 1775 - 20/08/1854). Filho de protestantes foi educado em estudos clássicos e bíblicos, conviveu com Hegel e Holderlin e lecionou nas mais importantes universidades alemãs. Suas obras foram conhecidas só após suas morte. Seus estudos voltam-se para a questão do "eu absoluto", do "eu incondicionado”, Deus. O mundo para Schelling dá-se a partir do espanto, da admiração. Este pensador resgata a experiência do espanto encontrada em Platão, a qual é a experiência da totalidade, da intuição estética. Ele acredita que somente a linguagem poética pode dar conta de falar sobre tal experiência. A poesia é, para o autor, a única forma possível para falar de Deus, de dizer sobre o indizível, o absoluto, o infinito. Deus é compreendido por ele como um fenômeno. Deus é natureza e gradativamente revela-se com as transformações da natureza, o que possibilita que Deus se auto-descubra o tempo todo. O eu, assim como as coisas, é uma forma finita de Deus. Para Schelling isso é liberdade, pois diz respeito a todas as possibilidades de ser, de revelação de infinito. Essa noção é contrária a de um Deus moral e dogmático e a da praxis de Kant. A tragédia do eu, para Schelling, é saber que a infinitude habita a finitude de seu corpo. Tal consciência dá ao homem a possibilidade de angustiar-se, pois ele sabe que dentro dele há um pedaço de Deus, sem, contudo, poder sê-lo. O homem traz com ele a missão de revelar-se e para isso precisa entrar em sintonia com o 
potências primordiais; e da fenomenologia de Rudolff Otto ${ }^{9}$ - na essência do Sagrado não há distinção entre divino e demoníaco. O que une essas três influências é a intuição de que o demônico não é um poder autônomo independente do sagrado, mas participa de sua própria essência.

\section{O Diabo na crista da onda da teoria}

Nunca tantos escreveram tanto sobre o Diabo como na atualidade. O herói recriado por Milton, retratado por Blake, adotado pelos românticos está na moda, agora sem a barba, os chifres e o rabo que o caracterizavam na Idade Média. Luther Link, em O diabo - A máscara sem rosto, defende a idéia que no Antigo Testamento Satanás não era adversário de Deus, mas o seu cúmplice. Para ele o Diabo não é uma pessoa e pode ter muitas máscaras, porém sua essência é uma máscara sem rosto. Link relembra que, para Espinosa, Deus entregou ao Diabo os pecadores. Deduz então que o Diabo é usado por Deus, trabalha para Deus, e nesse sentido não está em conflito com ele. Termina a introdução de sua obra e a apresentação desse personagem espinhoso afirmando:

O Diabo não é meramente uma criação literária. Ele é real, faz parte da realidade da civilização ocidental. Talvez o motivo de o Diabo despertar nosso interesse resida no fato do Diabo definir Deus tão seguramente quanto Deus o define. Graças a Deus pelo Diabo. (LINK, 1998, p. 22, negrito nosso).

Alberto Cousté, em sua Biografia do Diabo, apresenta idéias brilhantes e inovadoras sobre o biografado. Para ele não podemos fechar os olhos diante da evidência da sacralidade do Diabo. Aqui ele vai ao encontro da tese defendida pelo teólogo Tillich, que afirma que o Diabo é o sagrado com o sinal negativo e, no entanto, provém da mesma fonte de onde flui a graça. Cousté afirma que o Diabo sempre foi fiel ao homem e seu pavoroso drama de viver, e relembra que na Idade Média o Diabo era chamado de o macaco de Deus,

Absoluto. Há um mal no homem, quando ele distancia-se de sua limitação e julga-se ilimitado. É um revelar-se equivocadamente, pois nesse momento, distancia-se de Deus e da harmonia da natureza, iludindo-se enquanto possuidor de um poder divino.

${ }^{9}$ Rudolf Otto (25/09/1869 - 06/03/ 1937), eminente teólogo protestante alemão, erudito em religiões comparadas. Autor de The Idea of the Holy, publicado pela primeira vez em 1917 como Das Heilige (considerado um dos mais importantes tratados teológicos em língua alemã do século XX). Criador do termo numinous, o qual exprime um importante conceito religioso e filosófico da atualidade. 
já que o imitava em tudo. Também afirma que o Diabo não é propriedade de nenhum hermeneuta e que o grande problema de Lúcifer foi o seu equivocado amor pelos homens. Defende que Lúcifer é a mais alta potência da criação e que era dotado de uma agudíssima consciência de si mesmo. O referido autor diz que a única coisa que o Diabo quis era que os homens fossem iguais aos deuses. Termina a apresentação do biografado afirmando:

O Diabo é dor de Deus. Na medida em que amou Satã até o extremo de fazer dele a mais bela e luminosa de suas criaturas e na medida em que, apesar disso - ao haver-lhe dotado de livre arbítrio -, não pode impedir sua queda, Deus passou a sofrer por seu anjo imediatamente depois de tê-lo condenado. Desterrado da relação de puro amor que havia presidido sua criação e sua vida na glória, o Diabo foi condenado precisamente ao mais atroz dos castigos: $\mathbf{o}$ da incapacidade de amar. (COUSTÉ, 1996, p. 22, negrito nosso).

A tese geral de Cousté é a de que o que leva o Diabo a viver ruminando, desconsolado, impotente, tecendo armadilhas, é sua nostalgia do céu. Já para Northrop Frye, em sua obra Códigos dos Códigos, a base do papel que Satã representa na Bíblia é o papel de promotoria. (2004, p.76). Para Messadié, em sua História geral do Diabo, o mito do Diabo é um mito espinhoso; Gênesis é original por apresentar a serpente como prefiguração de Satanás; o Diabo não existe no Antigo Testamento, sendo que o Bem e o Mal são oriundos exclusivamente da vontade de Deus. Para esse crítico, no Novo Testamento Satanás perde o estatuto de membro do conselho celestial que tinha no livro de Jó e passa a ser o adversário de Jesus; portanto, é a partir do Novo Testamento que Satanás se divorcia de Deus. Messadié defende a idéia de que no Antigo Testamento Deus e o Diabo tinham relações extremamente secretas; foi a partir da grande crise do Judaísmo, com o nascimento de Jesus e a fundação da religião cristã, na charneira das duas eras, que o Diabo se define como inimigo confesso e eterno de Deus. Messadié formula a pergunta que não quer calar: Existe um ou muitos Satanás? (2001 p. 309). Respondemos à pergunta: muitos. E é por isso que Lúcifer/Satanás se apresenta como magnífico personagem para a Literatura, Pintura e Música, além de ser, é obvio, muito importante para a Teologia, quase tanto quanto Deus. 


\section{O Diabo na literatura ocidental}

Se os estudos teológicos e literários dão conta de uma Teopoética ${ }^{10}$ que se manifesta em vários autores, conforme o proposto por Kuschel em seu livro Os escritores e as escrituras, se a Teodicéia já foi proposta por Leibniz, se a epopéia de Cristo já foi centenas de vezes revisitada, quem afinal contou a epopéia de Lúcifer? Ou a antiépica de Lúcifer, ou aquilo que denominamos antiteodicéia de Lúcifer, ou Odisséia Luciferina? Ou Satanicéia? Se Deus, conforme tão bem apontou Miles em Deus - uma biografia, é um membro quase virtual da família ocidental e está impregnado no DNA da civilização ocidental - acrescentando-se que nenhum personagem no palco ou nas telas teve tanto sucesso como Ele - o que dizer do Diabo? De Lúcifer? Afinal, a outra face da moeda deveria acompanhar o sucesso Daquele? Será que só as estórias de Tróia, de Ulisses e de Jesus são suficientes para a humanidade, conforme lembrou Borges? E a magnífica trajetória de Lúcifer onde fica? Talvez ele esteja mais próximo do ser humano do que qualquer pessoa da Trindade, justamente por ter sido demasiadamente humano.

Ninguém pode ter o monopólio dos personagens bíblicos, muito menos do Diabo. Basta ver como ele transitou da Bíblia para magníficas páginas da literatura. A literatura se abriu como palco privilegiado e propício para contar a antiodisséia de Lúcifer, e em várias literaturas de várias línguas o Anjo de Luz foi retratado ou teve a oportunidade de narrar em primeira pessoa, por meio do espelho das palavras, a sua versão dos fatos. Seria uma tentativa insana relacionar todas as obras nas quais ele figura, ou como protagonista ou como coadjuvante. Citamos relances das obras de nossa preferência e também as mais conhecidas.

Na Divina Comédia, terminada em 1321, Dante Alighieri descreve o Inferno com riquezas de detalhes sensoriais e pictóricos, e o Diabo é retratado da seguinte forma: seu corpo é gigantesco, é horroroso (tanto quanto foi belo antes da queda), tem três caras em sua cabeça: a da frente é vermelha, a da direita tem uma cor entre o branco e o amarelo, e a da esquerda é negra. Ele possui seis enormes asas de morcego, que produzem o vento que congela 0

\footnotetext{
${ }^{10}$ A Teopoética foi proposta por Karl-Josef Kuschel. Trata-se de um novo ramo de estudos acadêmicos voltados para o discurso crítico-literário sobre Deus, sendo a análise literária efetivada por meio de uma reflexão teológica, o diálogo interdisciplinar possível entre Teologia e Literatura. Uma das principais perguntas da Teopoética é esta: qual o discurso dos autores sobre Deus, dentro da Literatura do século $\mathrm{XX}$ ?
} 
grande lago do Cocito; chora com seus seis olhos, e pelos três queixos escorre uma baba sanguinolenta. Em suas bocas, mastiga três traidores - na boca da frente, Judas, com a cabeça para dentro e as pernas para fora; nas outras duas bocas, Brutus e Cássio, presos pelas pernas, com a parte de cima do corpo pendurada para fora. Nessa obra não há um resgate do Diabo, ele está no mais profundo do Inferno com a missão de torturar os que traíram o seu próprio sangue (ou a sua confiança). O Inferno é assombrosamente maior que Lúcifer, que não passa de um detalhe daquele.

A antiodisséia de Lúcifer começa a ser retratada na obra $O$ Paraíso Perdido, de John Milton, publicada em 1667 e acrescida de dois novos cantos em 1674. Aqui o Satanás é o protagonista que luta contra os arcanjos, engana Uriel e acaba derrotado por Gabriel, Miguel e Rafael.

Fausto, o sábio alemão que vende sua alma ao demônio Mefistófeles em troca de conhecimento e poder, não foi criação de Christopher Marlowe. ${ }^{11}$ É uma lenda popular cuja autoria se perde no tempo. No século XVI, a história se tornou conhecida por meio do Faustbuch (O Livro de Fausto), obra anônima alemã que foi traduzida na Inglaterra. Era um texto moralista, provavelmente escrito por algum luterano furioso. Marlowe deu lustro estético à obra e resgatou a dignidade do personagem - que, no entanto, ainda desce ao inferno na cena final, de muito impacto junto ao público da época.

Caberia a outro alemão, Wolfgang von Goethe, salvar o atormentado Fausto, que em seu poema dramático é resgatado pelos anjos no ato final. O Fausto de Goethe é a versão mais conhecida do mito, o que torna o pacto com o Diabo uma temática universal. Impressionam-nos as semelhanças existentes entre Fausto e o Livro de Jó: o Senhor dialogando com Mefistófeles, permitindo que ele tente Fausto. Já no famoso Prólogo no Céu, Mefistófeles informa que o que o Diabo pretende é atormentar e seduzir os homens. Ele é irônico e debochado, ao afirmar que ver de perto o Eterno é motivo de orgulho para um simples Diabo. O ente incriado se autodefine assim: Eu sou aquele gênio que nega e que destrói! [...] Sou parcela do caos, onde nasceu a luz.

\footnotetext{
${ }^{11}$ Christopher Marlowe ( 26/02/1564 - 30/05/ 1593) foi dramaturgo, poeta e tradutor inglês que e viveu no período Elizabetano. Renovou a forma do teatro do período com a introdução dos versos brancos, estrutura que será empregada pelo próprio Shakespeare.

${ }^{12}$ Se Sartre, em Entre Quatro Paredes, afirma que "o inferno são os outros”, o personagem Mefistófeles, de Marlowe, vai bem mais longe e declara que "O Inferno é sem limites. Circunscrito / Não está a um lugar, pois, onde estamos, / Inferno é, e sempre aí estaremos”. 
(GOETHE, 2002, p. 59). Mefistófeles percorreu toda a alta literatura, do século XVI em diante.

Foi a partir do poeta e crítico Charles Baudelaire (1821-1867), precursor do simbolismo francês, que surgem na França os chamados poetas malditos. Em As Litanias de Satanás, o autor invoca a piedade do Tinhoso:

Ó tu, o Anjo mais belo e também o mais culto, Deus que a sorte traiu e privou do seu culto, Tem piedade, ó Satã, desta longa miséria!

Ocuparam-se do demônio outros escritores como Shakespeare, Thomas Mann e Paul Valéry.

Na peça teatral O Auto da Barca do Inferno, Gil Vicente coloca o Diabo e o Anjo no ancoradouro onde estão duas barcas: uma que conduz os salvos ao Céu e outra que conduz os pecadores ao Inferno. O Anjo é chato e enfadonho e o Diabo é galhofeiro, alegre, insulta a todos, tem um discurso irônico e sarcástico, canta e dança, e até discute em latim com o Juiz e o Bacharel. No final da peça só os cavaleiros cruzados entram na barca que vai para o Céu, mas a barca que vai para o Inferno está lotada e parece muito mais divertida e animada. No conto O Senhor Diabo, de Eça de Queirós, o escritor português enfatiza que a trajetória do Diabo é uma legenda trágica, luminosa, celeste, grotesca e suave. Para Eça,

o Diabo é a figura mais dramática da História da Alma. A sua vida é a grande aventura do Mal [...] o Diabo é o representante imenso do Direito Humano. [...] Tem talvez nostalgia do céu! [...] 0 Diabo amou muito. (QUEIRÓS, p. 4, negrito nosso).

No conto A Hora do Diabo, de Fernando Pessoa, o Diabo afirma, entre outras coisas, que tentou Jesus por incumbência de Deus e que ao negar Deus, ele o sustenta. Em primeira pessoa, o Diabo se define:

Eu sou aquilo a que tudo se opõe [...] sou negativo absoluto, a encarnação do nada. O que se deseja e se não pode obter, o que se sonha porque não pode existir - nisso está meu reino nulo e ai está assente o trono que me não foi dado. (PESSOA, 1997, p. 18 - 24).

Nesse conto, o Diabo diz que toda a estória envolvendo-os (ele e Deus) não passa de questões de família. 
Em O Evangelho Segundo Jesus Cristo de José Saramago, o Diabo é o protagonista, o grande herói deste desevangelho, aquele que entra na barca para salvar o salvador e toda raça humana. Pede perdão, Deus não aceita e o condena a ser eternamente o mal, o heterônimo, a outra face da medalha. O Diabo aqui é transformado na terceira pessoa da Trindade, ou melhor, na segunda pessoa da Trindade, uma vez que Jesus como humano não faz parte da tríade. Trata-se de uma Trindade que se resume em duplos siameses.

No Brasil muitas são as obras que tratam da Estrela da Manhã. Citamos apenas duas: Macário, de Álvares de Azevedo, e Grande Sertão: Veredas, de Guimarães Rosa, ambas retomando o mito de Fausto. Em Macário, o escritor romântico nos informa que o Diabo é a treva do não-ser. Macário não se assusta quando encontra o Diabo, pois esperava por ele há dez anos. E afirma: "A maior desgraça deste mundo é ser Fausto sem Mefistófeles. Olá Satã!" (AZEVEDO, 1855, p. 6). Riobaldo, o nosso Fausto sertanejo, filosoficamente debate com um interlocutor invisível a existência do Diabo e a possibilidade de pactuar com ele e vender a alma. Observemos como Guimarães Rosa coloca essa questão e os adjetivos que usa:

Principalmente a confirmação, que me deu, de que o Tal não existe; pois é não? O Arrenegado, o Cão, o Cramulhão, o Indivíduo, o Galhardo, o Pé-de-pato, o Sujo, o Homem, o Tisnado, o Coxo, o Temba, o Azarape, o Coisa-Ruim, o Mafarro, o Pé-preto, o Canho, o Duba-dubá, o Rapaz, o Tristonho, o Não-sei-que-diga, O-quenunca-se-ri, o Sem Gracejo... Pois, não existe! E, se não existe, como é que se pode se contratar pacto com ele? E a idéia me retorna. Dum mau imaginado, o senhor me dê o lícito: que, ou então - Será que pode também ser que tudo é mais passado revolvido remoto, no profundo, mais crônico: que, quando um tem noção de resolver a vender a alma sua, que é porque ela já estava dada vendida, sem se saber; e a pessoa sujeita está só é certificando o regular dalgum velho trato - que já se vendeu aos poucos, faz tempo? (GUIMARÃES ROSA, p. 29, 1988, negrito nosso).

Muito já foi escrito sobre esse livro (Grande Sertão: Veredas) e muito se escreverá, mas talvez a grande frase da obra seja Deus é definitivamente; o demo é o contrário Dele. (op. cit , p. 32)

Também existem várias antologias de contos sobre o Diabo, das quais citamos o livro O Diabo existe?, de Raimundo Magalhães Júnior, que traz um rico acervo de escritores que escreveram sobre o Diabo, como O Ar- 
quiinimigo Belfegor, de Machiavel; O Diabo Coxo, de Luis Vélez de Guevara; O Recibo do Diabo, de Walter Scott; Os três cabelos de Ouro do Diabo, dos Irmãos Grimm; O Moinho do Diabo, de Andersen; O Diabo no Campanário, de Edgar Allan Poe; etc.

Charles Darwin, com a publicação de A Origem das Espécies, em 1859, dispensou Deus para explicar a origem da vida no planeta Terra e nos legou como ancestral um macaco. Nietzsche matou Deus em sua obra A Gaia Ciência, publicada em 1888, quando na p.147, declara "Deus está morto! Deus continua morto! E nós o matamos!” E o que teria acontecido com Lúcifer? Parece que a partir de Nietzsche houve o que poderíamos chamar de desteificação do mundo, um mundo sem Deus. Esqueceram de matar o heterônimo indissociável de Deus e o mundo ficou desteificado? O que Machado de Assis tem a ver com a morte do Diabo?

\section{O Diabo em Machado de Assis}

Muito já foi escrito sobre Machado, citamos em seguida seus principais críticos: Alfredo Bosi, Astrogildo Pereira, Augusto Meyer, Harold Bloom, John Gledson, José Veriíssimo, Lúcia Miguem Pereira, Roberto Schwarz, Silvio Romero. No entanto, a obra de Machado continua sendo uma arca que ainda oferece tesouros a serem explorados. Se muito se escreveu sobre Machado, parece que há uma certa relutância em explorar toda a variedade da obra do escritor e isso resulta numa falta de renovação dos estudos machadianos, criando um paradigma de reprodução de novos trabalhos que ainda giram em torno de Schwarz e Bosi, como tão bem apontou Gledson. ${ }^{13}$ Também a chamada primeira fase do escritor, o Machado que existiu antes de Memórias Póstumas de Brás Cubas, publicado em 1881, é deixada de lado, e quando se explora essa fase, é na esperança de encontrar algo que ilumina o Machado maior. Mas a obra de Machado é muito maior do que os olhos oblíquos e dissimulados de Capitu pudessem prever. Muito já se escreveu sobre o adultério ou não de Capitu, e talvez isso fosse tudo que Machado não queria. Talvez essa abordagem o tivesse deixado realmente com os olhos de ressaca, aliás, o escritor de ressaca.

\footnotetext{
${ }^{13}$ Vide reportagem Começa o Ano Machado de Assis. In: Folha de São Paulo, Caderno Mais, 27.01.2008,
} p. 4. 
Um dos eixos preferidos na obra de Machado é o constante intertexto com a Bíblia, que pode ser constatado em Memórias Póstumas de Brás Cubas, Dom Casmurro, Esaú e Jacó e em vários contos. Alguns trabalhos já foram escritos explorando esse eixo da obra de Machado, mas talvez fosse o caso de se retomar tal linha de análise, agora com o instrumental teórico correto sobre os estudos comparados entre Teologia e Literatura.

O Diabo, como já afirmamos, se oferece como magnífico personagem para a literatura e Machado não deixou de explorá-lo, já que para ele $o$ diabo não é tão feio como se pinta... ${ }^{15}$ Sempre que se menciona a questão do Diabo na obra de Machado de Assis, nos vem à lembrança imediatamente o conto A Igreja do Diabo (1884). Mas existem outros dois contos em que ele aparece: Adão e Eva (1896), e O Anjo Rafael, publicado no Jornal das Famílias (1869).

No conto Adão e Eva o juiz-de-fora Veloso, insigne em teologia, para assombro do carmelita Frei Beto, afirma que as coisas no Paraíso não aconteceram como afirma o relato do Gênesis:

Em primeiro lugar, não foi Deus que criou o mundo, foi o Diabo... [...] - Seja o Tinhoso. Foi o Tinhoso que criou o mundo; mas Deus, que lhe leu no pensamento, deixou-lhe as mãos livres, cuidando somente de corrigir ou atenuar a obra, a fim de que ao próprio mal não ficasse a desesperança da salvação ou do benefício. E a ação divina mostrouse logo porque, tendo o Tinhoso criado as trevas, Deus criou a luz, e assim se fez o primeiro dia. (MACHADO DE ASSIS, 2008, p. 1, negrito nosso).

Observemos que o conto inverte toda a criação. O Diabo é o criador e Deus vai consertando o que não deu certo. Segue-se a narrativa da criação do primeiro casal: o Tinhoso cria Adão e Eva somente com ruins instintos, porque não podia infundir-lhes a alma. Deus conserta a criação do Tinhoso dando ao casal a alma, junto com sentimentos nobres e puros, e ainda um jardim de delícias. Impedido de freqüentar o jardim, o Diabo transforma a serpente em sua embaixatriz, concedendo a ela o dom da fala. O Diabo a

\footnotetext{
${ }^{14}$ Conforme estudos de Karl-Josef Kuschel, José Pedro Tosaus Abadía, Harold Bloom, Northrop Frye, Robert Alter, Kermode, Auerbach, Manzatto, Barcellos, Antonio Carlos Magalhães etc. Os principais pesquisadores na América Latina se concentram em torno da Associação Latino Americana de Literatura e Teologia (ALALITE).

15 Título do capítulo XCII de Dom Casmurro. 
descreve como serpe, fel rasteiro, peçonha das peçonhas e a instrui a tentar o casal a comer da árvore da ciência do Bem e do Mal, pois assim conheceriam o próprio segredo da vida:

Sim, o próprio segredo da vida. Vai, serpe das minhas entranhas, flor do mal, e se te saíres bem, juro que terás a melhor parte na criação, que é a parte humana, porque terás muito calcanhar de Eva que morder, muito sangue de Adão em que deitar o vírus do mal... Vai, vai, não te esqueças... (MACHADO DE ASSIS, 2008, p. 2, negrito nosso).

Nesse conto, o escritor dissocia a serpente do Diabo. São absolutamente dois seres distintos. A serpente invejosa e peçonhenta tenta o casal, Eva resiste e a chama de pérfida. A inteligência que caracterizava Lúcifer é transferida para a serpente, que num discurso poético responde:

- Néscia! Para que recusas o resplendor dos tempos? Escuta-me, faze o que te digo, e serás legião, fundarás cidades, e chamar-te-ás Cleópatra, Dido, Semíramis; darás heróis do teu ventre, e serás Cornélia; ouvirás a voz do céu, e serás Débora; cantarás e serás Safo. E um dia, se Deus quiser descer à terra, escolherá as tuas entranhas, e chamar-te-ás Maria de Nazaré Que mais queres tu? Realeza, poesia, divindade, tudo trocas por uma estulta obediência. Nem será só isso. Toda a natureza te fará bela e mais bela. (MACHADO DE ASSIS, 2008, p. 3)

Destacamos o lirismo do discurso da serpente, que é sedutora: diz a Eva que ela poderá voltar a terra como mãe do filho de Deus. A serpente prova que merece ser embaixatriz do Diabo, mas mesmo assim Eva resiste. Deus manda que Gabriel desça ao paraíso terrestre e busque o casal para viver no Paraíso celestial. E o Tinhoso e a serpente são amaldiçoados a viver na terra.

Já o conto A Igreja do Diabo é bastante conhecido. O início lembra o Livro de Jó e o prólogo de Fausto, de Goethe. Só que desta vez o Diabo se apresenta no céu, não para receber uma aposta de Deus, mas sim para informálo que vai fundar sua própria igreja. O intertexto com Fausto é evidente:

Há muitos modos de afirmar: há só um de negar tudo [...]

- Não venho pelo vosso servo Fausto, respondeu o Diabo rindo, mas por todos os Faustos de século e dos séculos. [...]

- Senhor, eu sou, como sabeis, o espírito que nega. (MACHADO DE ASSIS, 1997, p. 4 - 6, negrito nosso). 
O Diabo é descrito como tendo os olhos acesos de ódio, aquele que mora nas províncias do abismo. No diálogo entre os dois, Deus o define como um velho retórico, sutil, vulgar e sem criatividade. Por várias vezes o narrador descreve o Diabo rindo e sorrindo: O Diabo sorriu com certo ar de escárnio e triunfo. ${ }^{16} \mathrm{O}$ que o Diabo quer é fundar uma Igreja na qual as virtudes se transformariam em pecado e os pecados cristãos em virtudes. Enfim, quer trocar o certo pelo errado, tornar santo e aprazível o bigode do pecado. Quando volta à Terra, o Diabo - como numa espécie de evangelho profano - traz A Boa Nova aos Homens, confessa que é o Diabo e retifica seu caráter maculado pelas histórias que as beatas contavam dele:

Sim, sou o Diabo, repetia ele; não o Diabo das noites sulfúreas, dos contos soníferos, terror das crianças, mas o Diabo verdadeiro e único, o próprio gênio da natureza, a que se deu aquele nome para arredá-lo do coração dos homens. Vede-me gentil e airoso. Sou o vosso verdadeiro pai. Vamos lá: tomai daquele nome, inventado para meu desdouro, fazei dele um troféu e um lábaro, e eu vos darei tudo, tudo, tudo, tudo, tudo, tudo... (MACHADO DE ASSIS, 1997, p. 7, negrito nosso)

Nesse novo evangelho, o espírito de negação, com grandes golpes de eloqüencia, afirma que ele é o verdadeiro pai dos homens. Prega que a inveja, a soberba, a ira, a gula, a cólera, eram na realidade virtudes. O Diabo machadiano é um Diabo culto, já que conhece literatura e seus personagens. Cita Homero e defende a idéia de que sem a ira não haveria a cólera de Aquiles e sem a gula Rabelais não teria produzido suas melhores páginas. Citando um letrado padre napolitano, o Diabo recomenda: Leve à breca o próximo! Não há próximo. A única exceção é quando se trata da mulher do próximo.

A Igreja prospera e o Diabo dá gritos de triunfo: todos agora só fazem o bem, ou seja, só cometem os pecados anteriormente condenados, o errado é o certo. Só que o que o Diabo não imaginava é que as pessoas, às escondidas, começavam a praticar o mal, ou seja, praticar atos que no passado eram virtudes e agora estavam proibidas. Ele ficou pasmo, chegou aos céus, tremendo de raiva, ansioso, com uma agonia satânica. Deus não triunfa em cima do perturbado Diabo, olha para ele e diz:

- Que queres tu, meu pobre Diabo? As capas de algodão têm agora franjas de seda, como as de veludo tiveram franjas de algodão. Que

\footnotetext{
${ }^{16}$ Em História do Riso e do Escárnio, Georges Minois afirma que o riso sempre foi atribuído ao Diabo. 
queres tu? É a eterna contradição humana. (MACHADO DE ASSIS, 1997, p. 11, negrito nosso).

Chegamos então ao conto $O$ Anjo Rafael, que em relação ao tema enfocado neste artigo é o que mais nos interessa. Pela cronologia, verifica-se que esse conto foi o primeiro dos três aqui analisados: sua publicação se deu em 1869, no Jornal das Famílias. Entre os mais de duzentos contos de Machado, O Anjo Rafael é um dos menos conhecidos. Em 1973, Raymundo Magalhães Júnior publica pela editora Bloch a obra Contos Fantásticos de Machado de Assis, na qual está incluído o conto aqui analisado. Essa obra é reeditada pela mesma editora em 1998. Na introdução, o crítico chama a atenção para o que ele denomina de fantástico mitigado nos contos machadianos e alerta para o fato de que "a crítica pouco tinha atentado para essa faceta da obra de Machado." (MAGALHÃES JR. 1998, p. 3). Já Marcelo J. Fernandes, em sua dissertação de mestrado intitulada Quase-macabro: o fantástico nos contos de Machado de Assis, mesclando contos de sua escolha com alguns dos selecionados por Magalhães, faz uma análise da presença do fantástico e defende a tese de que Machado diluiu o fantástico naquilo que ele denomina de quase-macabro. $\mathrm{O}$ Bruxo do Cosme Velho gostava de incursionar pelo fantástico mitigado ou o fantástico quase-macabro, como tão bem destacaram os dois críticos aqui mencionados, afirmando que Machado desenvolve um padrão de fantástico. Mas nos interessa outro aspecto desse conto.

Resumindo o enredo do conto temos o seguinte: um jovem de 33 anos, tendo por nome Dr. Antero, resolve se matar. Naquela noite, quando estava prestar a se suicidar, recebe um criado com uma mensagem para que o acompanhe até a casa do seu patrão, Major Tomás. Antero resolve seguir o criado e chega a uma casa misteriosa. É apresentado ao Major, que afirma por várias vezes ser um ser celestial, o Anjo Gabriel, que, incompreendido em sua missão, tivera uma filha e agora se afastava do mundo. Porém, antes de morrer queria casar sua filha.

Observemos a criatividade e ironia de Machado nesse conto insólito, fantástico quase-macabro. Quando Antero vai se matar, ele faz uma bucha com uma folha do Evangelho de São João e coloca dentro da pistola. Na hora

\footnotetext{
${ }^{17}$ Em sua tese de mestrado, Marcelo J. Fernandes cria uma tipologia para definir o tipo de fantástico presente nos contos de Machado: conto gautieriano/ fantástico onírico (a tessitura da trama é detonada pelo sonho), influenciado por Gautier, e o fantástico insólito (fantástico anormal, um caso dentro de outro caso).
} 
derradeira do suicídio, ato contrário a toda lógica, Antero separa uma folha do Evangelho que começa por No princípio era o Verbo... As referências bíblicas são constantes em todo o texto: Antero mora na Rua da Misericórdia; na casa do Major sonha que, após ter tirado sua vida, Belzebu o mantinha queimando eternamente numa fogueira; a aparência do velho Major lembra um patriarca bíblico. O major insiste que foi criado por Deus, que tem origem no céu, que foi enviado do céu, que é o Anjo Rafael e que sua filha Celestina é um anjo na raça e na candura. A descrição que o narrador faz da moça é a descrição de um anjo: rosto angélico, virgindade do coração, cabelos louros e caídos em cachos e possuidora de uma auréola. Para o narrador, filha e pai pertencem a uma civilização desconhecida e o Dr. Antero se sente arrebatado nas asas da Fantasia em meio àquelas pessoas do céu. Antero se apaixona por Celestina e, após estar no sétimo céu, começa a perceber que seu futuro sogro era monomaníaco, pois acreditava ter origem celeste e ser o próprio Anjo Rafael:

- Eu sou, continuou o velho, eu sou o anjo Rafael, mandado pelo Senhor a este vale de lágrimas a ver se colho algumas boas almas para o céu. Não pude cumprir a minha missão, porque apenas disse quem era fui tido em conta de impostor. Não quis afrontar a ira e o sarcasmo dos homens; retirei-me a esta morada, onde espero morrer. (MACHADO DE ASSIS, 2008, p. 9, negrito nosso).

Antero confirma suas suspeitas: o velho era um monomaníaco e a filha ia pelo mesmo caminho. Esclarecemos que o anjo Rafael não é um personagem bíblico, ele só é citado em Tobias, um livro apócrifo que faz parte da chamada Bíblia católica, mas não faz parte da Bíblia protestante. Embora muito se fale do arcanjo Rafael, em nenhum dos textos desse apócrifo há a afirmação que Rafael seja arcanjo, mas apenas um anjo.... Eu sou Rafael, um dos sete anjos... (Tobias 12-15). Esse anjo Rafael fez coisas que parecem mais práticas de um anjo caído.

Chegamos ao ponto mais importante do conto: o monomaníaco celestial entra no quarto do Dr. Antero e lhe informa com a maior naturalidade:

Sabe quem morreu?

- Não.

- O diabo.

Dizendo isto deu uma gargalhada nervosa que fez estremecer o doutor; o velho continuou: 
- Sim, senhor, morreu o diabo; o que é grande fortuna para mim, porque me dá a maior alegria da minha vida. Que lhe parece? (MACHADO DE ASSIS, 2008, p. 12, negrito nosso)

O Anjo Rafael foi publicado em 1869, portanto exatamente 19 anos antes de A Gaia Ciência (1888), obra na qual Nietzsche matou Deus. Ou seja, o Machado menor, cujas publicações ocorreram antes de 1881, ano da publicação de Memórias Póstumas de Brás Cubas, fez o que o Machado maior, com as obras publicadas depois de 1881, não fez: matou o Diabo, bem antes de Nietzsche matar Deus. Só esse parágrafo, só essa idéia valeria por todo o conto.

Michel Onfray, em seu recente Tratado de Ateologia, no qual defende que os crentes sofrem de infantilismo mental e que o ateu é aquele que recuperou a sua saúde mental, afirma que a existência de Deus e do Diabo pertence ao mundo mágico, à fabula, e que toda crença é uma ficção. Sobre o Diabo, afirma ele: Satã, Lúcifer, o Portador da claridade - O filósofo emblemático das Luzes... -, aquele que diz não e não quer submeter-se à lei de Deus [...] o Diabo e Deus funcionam como frente e verso da mesma medalha, como teísmo e ateísmo. (ONFRAY, 2007, p. 6, negrito nosso).

Onfray aponta que Deus e o Diabo são faces da mesma medalha, teísmo e ateísmo. Discordo disso e vou mais além: frente e frente da mesma moeda - teísmo e teísmo. Como vimos anteriormente, a Igreja Católica considera a não crença no Diabo como heresia digna de excomunhão. Ou seja: se você não acredita em Deus, é um ateu; mas se você não acredita no Diabo, igualmente o é. Onfray afirma que um ateu é um ser incompleto, amputado, um sem-deus. Podemos asseverar, no entanto, que um ateu é, a partir de agora, um sem-diabo. Se coube a Nietzsche matar Deus em A Gaia Ciência, coube a Machado de Assis, dezenove anos antes, no conto o Anjo Gabriel, matar o Diabo. Tanto Nietzsche como Machado colocaram Deus e o Diabo no campo da filosofia ou da ficção (seres de papel). Mataram Deus e o Diabo e dessa forma, paradoxalmente, os mantiveram vivos, porque seres ficcionais não morrem nunca e, talvez, a filosofia continue a existir mesmo quando o homem não mais existir. Eis como o Bruxo do Cosme Velho matou Lúcifer...

Onfray afirma que o último deus desaparecerá com o último homem. Afirmamos que o último Lúcifer também desaparecerá com o último homem... 


\section{Bibliografia}

ABADÍA, José Pedro. A Bíblia como literatura. Petrópolis: Vozes, 2000.

AZEVEDO, Álvares. Macário. Biblioteca virtual do Estudante de Língua Portuguesa. <http:// bibvirt.futuro.usp.br>. Acesso em: jan 2008.

BARCELLOS, Carlos José. Literatura e teologia: perspectivas teórico-metodológicas no pensamento católico contemporâneo. In: Numen - Revista de Estudos e Pesquisa da Religião. Juiz de Fora: Editora da UFJF, v. 3, n. 2, p. 9-30, jul/dez 2000.

BATAILLE, Georges. A literatura e o mal. Porto Alegre: L\&PM, 1989.

BÍBLIA SAGRADA. Tradução de João Ferreira de Almeida. Edição revista e corrigida. Rio de Janeiro: Sociedade Bíblica do Brasil, [s.d].

COUSTÉ, Alberto. Biografia do diabo. Tradução de Luca Albuquerque. Rio de Janeiro: Rosa dos Tempos, 1996.

DAWKINS, Richard. Deus, um delírio. Tradução de Fernanda Ravagnani. São Paulo: Companhia das Letras, 2007.

DELUMEAU, Jean. História do medo no Ocidente (1300-1800). São Paulo: Companhia das Letras, 1989.

FLUSSER, Vilém de. A história do diabo.São Paulo: Anablume, 2004.

FERNANDES, Marcelo J. Quase-macabro: o fantástico nos contos de Machado de Assis. Rio de Janeiro: UFRJ, 1999. Dissertação de Mestrado.

FRYE, Northrop. O Código dos Códigos - A Bíblia e a literatura. Tradução de Flavio Aguiar. São Paulo: Boitempo Editorial, 2004.

GALIMBERTI, Umberto. Rastros do sacro. Tradução de Euclides L. Calloni. São Paulo: Paulus, 2003.

GOETHE, J. W. Fausto. Tradução de Alberto Maximiliano. São Paulo: Nova Cultural, 2002.

HARRIS, Sam. Carta a uma nação cristã. Tradução de Isa Mara Lando. São Paulo: Companhia das Letras, 2006.

JUNG, C.G. Resposta a Jó. Tradução de Dom Mateus Ramalho Rocha. 6. ed. Petrópolis: Vozes, 2001.

KUSCHEL, Karl-Josef. Os escritores e as escrituras. Retratos teológicos Literários. Tradução de Paulo Astor Soethe et alii. São Paulo: Loyola, 1999.

LINK, Luther. O diabo: a máscara sem rosto. Tradução de Laura Teixeira Motta. São Paulo: Companhia das Letras, 1998.

MACHADO DE ASSIS, Joaquim Maria. A igreja do diabo. In: Histórias sem data. Rio de Janeiro: Globo, 1997. (Obras Completas). 
MACHADO DE ASSIS, Joaquim Maria. Adão e Eva. In: Várias histórias. Disponível em: <http://www.biblio.com.br/conteudo/MachadodeAssis/adaoeeva.htm>. Acesso em: fev 2008.

MACHADO DE ASSIS, Joaquim Maria. O Anjo Rafael. In: Banco de Dados do NUPIIL. Disponível em: <http://alecrim.inf.ufsc.br/bdnupill/arquivos/texto/0037-01441.html>. Acesso em: fev 2008.

MAGALHÃES, Antonio. Deus no espelho das palavras - teologia e literatura em diálogo. São Paulo: Paulinas, 2000.

MAGALHAES, JR. Raimundo. Contos Fantásticos - Machado de Assis. Rio de Janeiro: Bloch, 1998.

. O diabo existe? Tomo I. Rio de Janeiro: Arte Nova, 1973.

MANZATTO, Antonio. Teologia e literatura - reflexões teológicas a partir da antropologia contida nos romances de Jorge Amado. São Paulo: Loyola, 1994.

MARTINS TERRA, J. E. Existe o diabo? Respondem os teólogos. São Paulo: Loyola, 1975.

MESSADIÉ, Gerald. História geral do diabo - da antiguidade à época contemporânea. Tradução de Alda Sophie Vinga. Portugal: Europa-América, 2001.

MILES, Jack. Deus - uma biografia. Tradução de José Rubens Siqueira. 3. reimpressão. São Paulo: Companhia das Letras, 1997.

MINOIS, Georges. História do riso e do escárnio. Tradução de Maria Helena Ortiz Assumpção. São Paulo: Unesp, 2003.

MUCHEMBLED, Robert. Uma história do diabo. Tradução de Maria H. Kühner. São Paulo: Bom Texto, 2004.

NEGRI, Antonio. Jó - a força de um escravo. Rio de Janeiro: Record, 2007.

NOGUEIRA, Carlos Roberto F. O diabo no imaginário cristão. São Paulo: Ática, 1986.

NUNES, Benedito. Teologia e filosofia - Aspectos teológicos da filosofia - o último deus. In: Crivo de Papel. 2. ed. São Paulo: Ática, 1998.

ONFRAY, Michel. Tratado de ateologia. Tradução de Mônica Stahel. São Paulo: Martins Fontes, 2007.

OTTO, Rudolf. O sagrado. Tradução de Walter O. Schlupp. Porto Alegre: Sinodal/EST, Petrópolis: Vozes, 2007.

PAGELS, Elaine. As origens de satanás. Tradução de Ruy Jungmann. 2. ed. São Paulo: Ediouro, 1996.

PESSOA, Fernando. A hora do diabo. Lisboa: Assírio \& Alvim, 1997.

QUEIRÓS, Eça de. O senhor diabo. Disponível em <http://www.virtualbooks.terra.com. br>. Acesso em 28 mar 2008. 
Salma Ferraz

QUEVEDO, G. Oscar. Antes que os demônios voltem. São Paulo: Loyola, 1989.

ROSA, Guimarães. Grande sertão: veredas. Rio de Janeiro: Nova Fronteira, 1986.

SANTOS, Walmor. Além do medo e do pecado. Porto Alegre: Mercado Aberto, 1996.

SCHELLING, Friedrich W. Joseph.<http://www.pucsp.br/filopuc/verbete/schellin.htm> Acesso em: 30 mar 2008.

SOB A SOMBRA DO DIABO. In: Revista História Viva - grandes temas. Edição

ESPECIAL Temática n. 12. São Paulo: Duetto Editorial, 2006.

STANFORD, Peter. O diabo - uma biografia. Tradução de Márcia Frazão. Rio de Janeiro: Gryphus, 2003.

TILLICH, Paul. Filosofia de la religion. Buenos Aires: La Aurora, 1969. p. 74.

WENISCH, Bernhard. Satanismo. Tradução de Edgar Orth. Petrópolis: Vozes, 1992.

Recebido para publicação em 28 de agosto de 2008. Aceito para publicação em 30 de novembro de 2008. 